\title{
THE IMPORTANCE OF LAND REGISTRATION TO SUPPORT SUCCESSFUL ENVIRONMENTAL MANAGEMENT
}

\author{
Mira Novana Ardani \\ Faculty of Law, Diponegoro University, Indonesia \\ miranovana@yahoo.com
}

\begin{abstract}
Land registration provides legal certainty and protection to holders of land rights. In its implementation it does not always go well, so that what is the goal can not be achieved. A person or legal entity cannot prove that he is the legal owner of a parcel of land. This can lead to land conflicts. Land conflicts can cause overlapping land tenure and overlapping land permits which often results in environmental damage. This research uses a normative juridical approach. Normative juridical research is research focused on examining the application of rules or norms in positive law. The research objective is to find out what ways can be done so that through land registration activities can support the success of environmental management. The results of the study explained that land registration activities through systematic land registration acceleration resulted in land certification for plots of land that had met the requirements, and could strengthen the one map policy database, so that administrative order could be achieved. It also makes land use plans to support the achievement of national development goals and the greatest prosperity of the people, so as to realize environmental sustainability.
\end{abstract}

Keywords: Land registration; Management; Environment

\section{Introduction}

The earth, water, natural resources contained therein are at the highest level controlled by the state as the largest organization of the people of Indonesia. The government makes a general plan regarding its supply, designation and use for various purposes. One of the ways carried out by the government, especially in land law so that lands in Indonesian territory are guaranteed legal certainty in the land sector is by holding land registrations. ${ }^{1}$ By holding a land registration, the parties concerned can easily find out the legal status or position of the particular land it faces, its location, area and boundaries, who owns it and what burdens are on it. $^{2}$ In its implementation, this land registration activity was not in accordance with what was expected. There are still lands that have not been registered. The government continues to make efforts so that all regions in the Republic of Indonesia can be registered. This is in accordance with the mandate contained in Article 19 of the Undang-Undang Pokok Agraria (UUPA), that to guarantee legal certainty by the government land registration is carried out throughout the territory of the Republic of Indonesia. It is not easy to carry out land registration that covers the entire territory of the

\footnotetext{
Samun Ismaya, Hukum Administrasi Pertanahan (Yogyakarta: Graha Ilmu, 2013).

2 Effendi Perangin, Hukum Agraria Indonesia (Jakarta: Rajawali Press, 1990).
} 
Republic of Indonesia. In the framework of achieving all land parcels in the Republic of Indonesia to become registered, there is an effort made by the government, namely by setting a gradual target for the inclusion of land rights in all regions of Indonesia.The Minister of Agrarian Spatial Planning / Head of the National Land Agency installed a taget of 11 million land certificates in 2019, and is complete certifying all land by 2025. The target of awarding land certificates given by the President is increasing every year. In 2017, the Ministry of Agrarian Spatial Planning / Head of the National Land Agency issued 5.4 million certificates. In 2018 it increased to 9.4 million certificates that were successfully issued. Furthermore, in 2025 it is targeted that all land will be registered. With the registration of lands throughout Indonesia, it is expected that a person or legal entity can have a certificate of ownership of land, so that it can prevent illegal ownership of land, and can be used as evidence to other parties who need information about the relevant land. . However, as long as the administrative order in the land sector in the entire territory of the Republic of Indonesia, namely in terms of land registration, has not yet been carried out, it is still very possible to cause conflicts in the land sector, even to the point of being an environmental problem. Land conflicts, usually involve the community with the community, the community with the government, and the community with the company. ${ }^{3}$ For example, land conflicts can lead to overlapping land ownership or overlapping land permits which often result in environmental damage. As happened in the control of plantation land. If the permit related to the given land area is not right, for example, it is too broad, while the investor is constrained by the limited capital owned to utilize the land, then the possibility arises that the land may be abandoned, so that what is the purpose of giving the right to make an estate is not achieved, and the land becomes unproductive. ${ }^{4}$ Of course it will have an impact on the environmental sustainability of the land concerned, for example related to the fertility of the land which can be decreased. Likewise with the inaccurate boundaries between land for Hak Guna Usaha (HGU) of plantation land and farmer land, each claiming to be the owner of the land in question. This also has the opportunity to not utilize the land that is in dispute over the boundary, so that it becomes displaced, and can cause environmental damage. Another example that occurred in the Brazilian Amazon. the main causes of deforestation in the Brazilian Amazon rainforest. Another important conclusion is that most deforestation, at least

3 CNN Indonesia, "BPN Target Terbitkan 11 Juta Sertifikat Tanah Gratis Di 2019," CNN Indonesia, 2019, https://www.cnnindonesia.com/nasional/20190321134316-20-379420/bpn-target-terbitkan-11-juta-sertifikattanah-gratis-di-2019.

4 Herawan Sauni, "Konflik Penguasaan Tanah Perkebunan," University of Bengkulu Law Journal (UBELAJ) 1, no. 1 (2016): 61. 
during the years of 2012 and 2013, occur redonlands either directly or indirectly controlled by the State, thus demonstrating that alack of land governance is a very important part of the deforestation dynamics. ${ }^{5}$ Then the problem arises, how can through land registration activities be able to support the success of environmental management?

\section{Methods}

The method is a guide to the way a scientist learns and understands the steps faced. ${ }^{6}$ Research is a basic tool in the development of science and technology. Research aims to reveal the truth systematically, methodologically, and consistently. ${ }^{7}$ This research will be prepared using a type of normative juridical research, which is research focused on examining the application of the rules or norms in positive law. ${ }^{8}$ This normative research is defined as research that can be done by examining library materials, which can be in the form of primary legal materials, secondary legal materials, and tertiary legal materials.

In this writing using secondary data that includes official documents, library books, legislation, scientific work, articles, and documents related to research material. The secondary legal material includes three parts, namely:

1. Primary legal material

Primary legal materials, namely binding legal materials. The primary legal material used in this study consists of statutory regulations, namely the Basic Agrarian Law, the Regulation of the Minister of Agrarian Affairs and Spatial Planning / Head of the National Land Agency, and other legislation that can support this writing.

2. Secondary legal material

Secondary legal material, which provides an explanation of primary legal material, such as, research results, work from legal circles, and so on.

3. Tertiary legal material

Tertiary legal materials, namely materials that provide instructions and explanations for primary and secondary laws; Examples are encyclopedias, dictionaries, cumulative indexes and so on.

5 Bastiaan; Vitor BukvarFernandes and Tiago SantosTelles Philip Reydon, "Land Governance as a Precondition for Decreasing Deforestation in the Brazilian Amazon," Elsevier Journal, Land Use Policy 94, no. 104313 (2020).

6 Soejono and Sri Mamudji Soekanto, Penelitian Hukum Normatif, Tinjauan Singkat (Jakarta: Raja Grafindo Persada, 2007).

7 Ibid.

8 Johnny Ibrahim, Teori Dan Metodologi Penelitian Hukum Normatif (Malang: Bayumedia, 2006). 
The method used in collecting data in this research is to do a literature study, which is collecting data by searching and reviewing library materials that can be in the form of research results, literature, scientific magazines, and others. The results of the study were analyzed using the provisions governing both the land law and environmental law. The presentation is in the form of descriptions arranged systematically, meaning that the secondary data obtained will be linked to one another according to the problem under study, so that the whole is a unified whole in accordance with research needs.

\section{Results and Discussion}

Providing guarantees of legal certainty in the land sector requires two aspects, namely: ${ }^{9}$ (1) Availability of written legal instruments, which are complete and clear and implemented consistently; (2) Effective land registration.

With the availability of written legal instruments, anyone who has an interest will easily know what possibilities are available to him to control and use the land he needs, how to obtain it, rights, obligations and what restrictions exist in controlling land with rights. certain rights, what sanctions he faces if the relevant provisions are ignored, as well as other matters relating to the control and use of the land he owns.

To obtain information about the location of the land, land boundaries, land area, building and/or what plants are on it, what is the status of the land, who is the right holder, all of it is necessary to know from the beginning before for example someone will do legal actions against the land concerned to prevent future disputes. With the holding of the land registration, then: (1) Those who own land will easily be able to prove their rights to the land they controlled and own. To each of them was given a letter of proof of rights by the government; (2) Those who need the information intended, namely prospective buyers and prospective creditors who will receive land as collateral, will easily obtain it, because the information is kept in the Office of Land Registry, open to the public. In a general sense may know, by looking at the list and documents concerned or requesting written information about the data needed from the office. ${ }^{10}$

Implementation of land registration is the basis for establishing legal certainty. In the provision of Article 19 paragraph (1) of Law Number 5 of 1960 concerning the Undang-Undang Pokok Agraria (UUPA), it is stated that in order to guarantee legal certainty by the government

\footnotetext{
9 Boedi Harsono, Hukum Agraria Indonesia, Sejarah Pembentukan Undang-Undang Pokok Agraria, Isi Dan Pelaksanaannya (Jakarta: Djambatan, 2008).

10 Ibid. p. 6
} 
land registrations are held throughout the territory of the Republic of Indonesia. Article 19 is addressed to the government as an instruction, so that in all regions of Indonesia land registration is carried out in a "rechts-cadastral" nature, meaning that it aims to guarantee legal certainty. Whereas the provisions of Article 23, 32 and 38 of the UUPA are addressed to the relevant rights holders, with the intention that they obtain certainty about their rights. ${ }^{11}$

The definition of land registration in accordance with Government Regulation Number 24 of 1997 concerning Land Registration is a series of activities carried out by the Government on an ongoing, continuous and regular basis, including the collection, processing, bookkeeping, and presentation and maintenance of physical and juridical data, in the form of maps and a list, concerning plots of land and units of flats, including the granting of proof of rights for plots of land for which there are already rights and ownership rights over the units of flats and certain rights which burden them.

Land registration is not only intended to guarantee legal certainty of the rights to the land it owns, due to obtaining proof of rights, but also to obtain legal protection. Legal protection is an act that has the character to protect and / or provide assistance to sufferers whose rights are deprived or impaired. ${ }^{12}$

In order to accelerate the implementation of land registration in the territory of Indonesia, a comprehensive systematic land registration is held, which has the understanding of the activities of the Land Registration for the first time carried out simultaneously for all objects of Land Registration in the entire territory of the Republic of Indonesia in one rural / urban area or other name at the same level, which includes the collection of physical and juridical data regarding one or several Land Registration objects for the purpose of registration. The arrangement can be found in the Regulation of the Minister of Agrarian and Spatial Planning / Head of the National Land Agency of the Republic of Indonesia Number 6 of 2018 concerning Complete Systematic Land Registration.

Understanding the environment in accordance with Law Number 32 of 2009 concerning Environmental Protection and Management, Article 1 is the unity of space with all objects, power, conditions, and living things, including humans and their behavior, which affect nature itself, the survival of life, and the welfare of humans and other living things.

Ibid. p. 582

12 Yudhi; Boedi Djatmiko Hadiatmodjo and Imam Ropii Setiawan, Teori Dan Praktik Administrasi Hukum Pemerintah (Dilengkapi Dengan Beberapa Masalah Tanah) (Jakarta: Rajawali Press, 2017). 
Environmental protection and management is a systematic and integrated effort undertaken to preserve environmental functions and prevent environmental pollution and/or damage which includes planning, utilization, control, maintenance, supervision, and law enforcement.

The organizer of the land registration activity is the government, through the National Land Agency. In the provisions of Article 19 UUPA, land registrations are held throughout the territory of the Republic of Indonesia. In order to accelerate the implementation of land registration whose territory is determined for all regions in Indonesia, a comprehensive systematic land registration activity is held. The purpose of holding a complete systematic land registration activity in accordance with Article 2 of the Regulation of the Minister of Agriculture and Spatial Planning / Head of the National Land Agency of the Republic of Indonesia Number 6 Year 2018 is to realize the provision of legal certainty and legal protection of community land rights based on simple, fast, smooth, safe, fair, equitable and open and accountable, so as to improve the welfare and prosperity of the community and the country's economy, as well as reduce and prevent land disputes and conflicts.

The object of a complete systematic land registration includes all parcels of land without exception, both parcels of land for which there are no land rights or parcels of land that have rights in order to improve the quality of land registration data. The results of the systematic land registration activities, in accordance with Article 38 of the Minister of Agrarian and Spatial Planning / Head of the National Land Agency of the Republic of Indonesia Number 6 of 2018 is used to strengthen the one map policy database. The acceleration of the one map policy is mandated in Presidential Regulation Number 9 of 2016 and is part of the Economic Policy Package VIII. The Economic Policy Package is believed to be a solution to respond to various challenges and obstacles during the development process which often leads to overlapping land use conflicts. ${ }^{13}$ In addition, environmental issues are very important, because they are on the agenda in the current government, which is included in Nawacita volume 2 on environmentally sustainable development. For example, the government resolves agrarian conflicts by distributing land certificates. This has a solution for environmental problems. ${ }^{14}$

This one map policy will be useful for the central government (ministries / institutions) and regional governments in various geospatial data and information to synchronize and improve

13 Satupeta, “Tentang Akselerasi Kebijakan Satu Peta (PKSP)," Satupeta, 2019, https://satupeta.go.id/about.

14 Christoforus Ristianto, "Timses Jokowi Sebut Isu Lingkungan Jadi Program Nawacita Jilid 2," Kompas, 2018, https://nasional.kompas.com/read/2018/12/20/18203121/timses-jokowi-sebut-isu-lingkungan-jadi-programnawacita-jilid-2. 
geospatial data so that it becomes a reference for all ministries or institutions and local governments in issuing permits and policies. Another benefit, every level of government with the policy of one map, will use the same basic map, because it uses one map of the same area, land that has been issued a management permit, can not be issued a management permit on the same plot of land. That is, it can avoid overlapping issuance of permits over land management. For example, mining permits have been granted, but plantation licenses (overlapping permits) have also been granted. It is expected that with the formation of one map policy there will be no such thing. 15

In other words, the existence of this one map policy can minimize land disputes that can adversely affect the environment. Juni Thamrin said the source of the triggering of land conflict cases which subsequently emerged as a form of dispute in various regions in Indonesia could be identified in several categories as follows: ${ }^{16}{ }^{17}$ (1) Problems relating to plantation land, including: (a) The compensation process that has not been completed is accompanied by intimidation; (b) The acquisition of people's arable land that has been managed for more than 20 years for plantation land; (c) The difference in the size of the measurement results with the Cultivation Right (HGU) of the plantation; (d) Plantations are on customary or clan or inherited land; (2) Problems with the application for land rights related to forest area claims, especially those that are no longer physically functioning as forests; (3) Problems with disputes over court decisions include but are not limited to: (a) Not received a court decision by the party to the dispute; (b) Court decisions that cannot be executed because the status of ownership and ownership has changed; (c) Court decisions lead to different legal consequences on the status of the same object; (d) Certain applications are based on court decisions that do not have permanent legal force; (4) Issues on land disputes and land registration and overlapping certificates on the same land; (5) The problem of reclaming and reoccupying land that has been released by the housing developer due to manipulated compensation; (6) Land issues over customary / customary land claims; (7) Problems relating to the mechanism of exchange of land, especially crooked land that has become village land; (8) Other problems that cannot be categorized in the seven categories above, such as misuse of location permits.

15 Ana Silviana, "Kebijakan Satu Peta Yang Mencegah Konflik Dalam Administrasi Pertanahan," Hukum Administrasi \& Jurnal Tata Pemerintahan 2, no. 2 (2019).

16 Juni Thamrin, "Gagasan Menuju Pada Pengelolaan Sumber Daya Agraria Yang Partisipatif Dan Berkelanjutan," Jurnal Analisis Sosial 6, no. 2 (2001).

17 Nia Kurniati, Hukum Agraria Sengketa Pertanahan Penyelesaiannya Melalui Arbitrase Dalam Teori Dan Praktik (Bandung: Refika Aditama, 2016). 
The resulting map will include the location, type of rights and subject of rights. Equipped with corridor measurements. Our map will become a multiuser map that can be used by all agencies, not just Badan Pertanahan Nasional (BPN). This one map policy is like putting together a puzzle. He will not provide real information if all the parts have not been arranged properly. Complete land information is presented on a map in accordance with the provisions that have been set together, can be a reference for sustainable development. ${ }^{18}$

Providing information in the form of one map policy will certainly be very helpful in developing the country. The existence of one map policy can also help in the formulation and implementation of regional spatial planning to create integrated spatial planning that is harmonious with environmental sustainability. This can be seen in one of the instruments for preventing pollution and / or environmental damage that can originate from spatial planning, in accordance with the provisions contained in Undang-Undang Nomor 32 Tahun 2009 tentang Perlindungan Dan Pengelolaan Lingkungan Hidup (Law Number 32 of 2009 concerning Environmental Protection and Management). To be able to realize this, the government in accordance with its role, as the holder of power of the people of Indonesia with the right to control from the state, which is contained in Article 2 UUPA, one of them is realized by the government's authority in the implementation of spatial planning. The authority of the government in the management of spatial planning is regulated in Article 8 of Law Number 26 of 2007 concerning Spatial Planning, including: (a) Regulating, fostering, and supervising the implementation of national, provincial and district / city regional spatial planning, as well as the implementation of national, provincial and district / city strategic regional spatial planning; (b) Implementation of national spatial planning; (c) Implementation of national strategic area spatial planning; and (d) Collaboration on spatial planning between countries and facilitating spatial cooperation between provinces.

Whether a development is successful or not depends on the existence of a plan, implementation, and supervision. The function of supervision, coordination, and synchronization is very necessary so that development does not deviate from the planned plan and does not overlap and conflict with each other's functions and uses so that harmony in the physical development and its benefits can be achieved. ${ }^{19}$

18 Kantor Pertanahan Surabaya, "Mendukung Satu Kebijakan Peta Kantor Pertanahan Kota Surabaya Meluncurkan Kota Yang Lengkap," Kantor Pertanahan Surabaya, 2018, https://www.atrbpn.go.id/News/ Press Release /.

19 Hasni, Hukum Penataan Ruang Dan Penatagunaan Tanah Dalam Konteks UUPA-UUPR-UUPLH (Jakarta: Rajawali Press, 2008). 
Development of spatial information and communication systems, carried out through the provision of databases and information on spatial planning by developing electronic system networks. This was stated in Article 15 paragraph (2) of Government Regulation Number 15 of 2010 concerning Implementation of Spatial Planning. Providing databases and information on spatial planning will be greatly helped if there is already an integrated map that is not only on the National Land Agency, but all agencies that need it can easily access it.

In Law Number 26 of 2007 concerning Spatial Planning, it is stated that spatial planning, structure and spatial patterns include land use, water use and other resources. In this connection, land use management is an inseparable part of spatial planning, or subsystem of spatial planning. At this time land stewardship is the most dominant element in the spatial planning process. ${ }^{20}$ The land use plan is a tangible form of the implementation of Articles 2, 14, and 15 of the UUPA which is also imbued with other laws that deal with land use.

In line with Article 14 of the UUPA, Article 15 of the UUPA is also closely related to environmental sustainability. Maintaining land, including increasing its fertility and preventing damage, is the obligation of each person, legal entity or agency that has a legal relationship with the land, taking into account economically weak parties. The use contains the obligation to maintain the preservation of the ability of the land and prevent damage to the land, in accordance with the purpose of the granting, the content of the rights, as well as the designation of the land has been determined in the spatial plan of the area where the land is located. ${ }^{21}$

The provisions contained in Article 15 of the UUPA cannot be separated also from what is stated in Article 6 of the UUPA, that all land rights have a social function. In the clarification of the UUPA it is said that the social function implies that any rights to land that exist in a person cannot be justified, that his land will be used (or not used) solely for his personal interests, especially if it causes harm to the community. In line with this, the right of the state to not be absolute because it is limited by the provisions stipulated in the principles of our country's law and may not conflict with human rights. Provisions on state rights regulated in the 1945 Constitution (UUD 1945) must be seen as general and special relations. In general, anyone or an individual has the right to own property rights but in special circumstances these individual property rights can be arbitrarily expropriated by the state. That is, if individual property rights are needed for the public interest then individual property rights must be defeated, it is understood that individual property rights are not absolute. In the implementation of defeating

20 Ibid. p. 36

21 Adrian Sutedi, Peralihan Hak Atas Tanah Dan Pendaftarannya (Jakarta: Sinar Grafika, 2006). 
individual property for the public interest, "control rights" by the state are applied, and this is the nature of populism from UUPA Number 5 of 1960 which prioritizes the rights of ordinary people as pressure without removing individual rights. The term to control in the constitution does not mean to be a direct owner, but to regulate how property rights occur and how methods to convert that property into other rights for other parties for the public interest. ${ }^{22}$

The purpose of the land use plan is to regulate the supply, designation, use of the land in order to provide LOSS benefits (Sustainable, Optimal, Harmonious, Balanced). The function of the land use plan is not only as a land supply procedure, but also as a direction for land use activities, both short and long term, in connection with the development plan. The land use plan must clearly define development policies so that the land use plan is prepared after the development policy is inherited. ${ }^{23}$

Article 2 UUPA in paragraph (2) affirms that the state as an organization of people's power includes the authority to regulate and organize the use of land. Article 14 UUPA in its explanation states that in order to achieve that the use of land for the greatest prosperity of the people, it is necessary to have a plan regarding the supply, allocation, and use of the earth, water and space. The government, in this case the ratification of regional government regulations must be carried out within the framework of a general plan made by the central government and in accordance with central policy. In the UUPA there is no confirmation of the meaning, inventory, and use of the land. However, it appears that the purpose of each plan is none other than to realize the ideals contained in Article 33 of the 1945 Constitution (Undang-Undang Dasar 1945), namely for the prosperity of the people. ${ }^{24}$

In the land use sector too, one of the data needed to make decisions for the Regional Government in addition to the facts of the region is the usage data. Inventory results from processing land use data are presented one of them in a land use map that illustrates the location of various types of land use. ${ }^{25}$

In order to meet diverse development needs, it is necessary to develop spatial patterns that harmonize land use, water use and other natural resources in a harmonious, dynamic and longterm environment. The impact of development in big cities can lead to the growth of settlements

\footnotetext{
22 Aartje Tehupeiory, "Legal Protection To Individual Rights In Land Procurement For Public Interest," Diponegoro Law Review 2, no. 1 (2017).

23 Hasni, Hukum Penataan Ruang Dan Penatagunaan Tanah Dalam Konteks UUPA-UUPR-UUPLH. p.36

24 Dian Ekawaty Ismail, Hukum Tata Ruang, Rekonstruksi Menuju Pemukiman Indonesia Bebas Kumuh, (Bandung: UII Press: 2018), 122.

25 Hasni, Hukum Penataan Ruang Dan Penatagunaan Tanah Dalam Konteks UUPA-UUPR-UUPLH. P. 50
} 
in the city center. Some form settlements in accordance with the function of the land, but there are also settlements that are slum. These slums arise from the existing urbanization, which can result in social problems. Slums that occur have a negative effect on both the inhabitants and the surrounding environment. Slums in urban areas can be caused by several factors, including: ${ }^{26}$

1. Land legality

Being in an illegal location. Dwellings are built on state-owned land or other people. This is due to the low public awareness of the legality of building construction.

2. Build in a dense area

The city is a magnet for its people so many people open businesses in the city center and live in settlements around the city center. They tend to occupy land near the labor market (non-formal) where the density exceeds 500 people per ha. The number of houses is very dense and the size is below standard. The irregularity of the building where people live is one of the causes of the process towards slums.

3. Permission

Some slums do not have permits issued by local governments. Among the construction of settlements in the hills because usually this area has a fairly high slope level (above 40\%) and settlements in areas that are in direct contact with water (on the banks of rivers, lakesides, and beaches).

4. Violating the Spatial Planning Law (Undang-Undang Penataan Ruang)

Urban spatial planning needs to be based on an understanding that urban development must be carried out in accordance with the carrying capacity of the city, including the relatively low carrying capacity in the slum environment. Incorrect investment in spatial use, will have an impact on damaging the environment which then has the potential to encourage the growth and development of slums or new enclaves. This happens because of a lack of understanding of spatial planning rules both for the community and development policy makers.

5. Inadequate infrastructure

Lack of facilities and infrastructure or not meeting technical and health requirements are also common in slums.

26 Dian Ekawaty Ismail, Hukum Tata Ruang, Rekonstruksi Menuju Pemukiman Indonesia Bebas Kumuh (Yogyakarta: UII Press, 2018). P. 188 
Problems with slums can be overcome by applying the right rules. Both of the laws and regulations and local regulations. Provisions governing spatial planning, licensing and land registration must be applied in a strict and consistent manner.

Land use management which is a government effort and contains arrangements and implementation of allotment, inventory and use of land must be able to inspire and realize land tenure and land use management plans and the transfer of land rights need to be continued and developed in order to realize an orderly check of land (legal order) land, orderly administration, orderly use of land, and orderly maintenance of land and the environment) as an effort to realize a dynamic regional land use plan. Land use management which is expected in essence is aimed at guaranteeing: (1) The realization of an orderly use of land and orderly maintenance of land and the environment; (2) The purpose of allocating land according to the regional spatial plan and the existence of certainty in the use of land for every person and legal entity that has a legal relationship with the land; (3) The purpose of providing land for various needs of development activities carried out both by the government and the community in accordance with the regional spatial plan. $^{27}$

To maintain the integrity of the use of spatial functions for environmental preservation can be done with a preventive and repressive law enforcement strategy. Preventive law enforcement on the use of spatial structures that support environmental sustainability can be done by preventing various activities in the form of policy making that can be indicated to damage the environmental order. Likewise, lawful enforcement must be taken firmly to anyone who is wrong in using spatial planning and the environment. For policy makers who make the wrong spatial planning and those that do not comply with the spatial principles as intended in the legislation must be given severe sanctions. For communities and some businessmen who are found to be damaging to the environment, for example through logging activities, they must be given severe sanctions as well. ${ }^{28}$

In relation to sanctions, Article 52 of the UUPA regulates criminal provisions for those who violate Article 15 of the UUPA, that is, anyone who intentionally violates the provisions in Article 15 shall be liable to a maximum sentence of three months and / or a maximum fine of $\mathrm{Rp}$ 10,000.00. Of course the application of these sanctions is not effective. Between the penalty and the impact caused by not maintaining the soil, it causes disruption to fertility and environmental

Ibid. p.33

28 Suwitno Y.Imran, “Fungsi Tata Ruang Dalam Menjaga Kelestarian Lingkungan Hidup Kota Gorontalo,” Jurnal Dinamika Hukum 13, no. 3 (2013): 457. 
damage is not proportional to the fines imposed. So the implementation of sanctions related to land use must be strictly regulated and applied in other legislation, such as environmental laws. One of the permit requirements in the field of environmental law is that these business activities must have an Environmental impact assessment (Analisis Dampak Lingkungan) that ensures that the business activities do not have a large and significant impact on the environment. ${ }^{29}$ This environmental impact assessment permit, of course, also pays attention to the spatial layout of the region concerned.

In the management of spatial planning, it must be carried out based on the principles regulated in the Spatial Planning Law, namely: (a) Integration: that spatial planning is carried out by integrating a variety of interests that are cross-sectoral in nature, and across stakeholders (including the central government, regional governments, and the community); (b) Harmony, and balance: that spatial planning is carried out by realizing harmony between spatial structure and spatial patterns, harmony between human life and the environment, growth and development balance between regions and between urban and rural areas; (c) Sustainability: that spatial planning is carried out by ensuring the preservation and continuity of the carrying capacity and carrying capacity of the environment by taking into account the interests of future generations; (d) Efficacy and effectiveness: that spatial planning is carried out by optimizing the benefits of space and the resources contained in it and ensuring the realization of quality spatial planning; (e) Openness: that spatial planning is carried out by giving the widest access to the public to obtain information related to spatial planning; (f) Togetherness and partnership: that spatial planning is carried out by prioritizing the interests of the community; (g) Legal certainty and justice: that spatial planning is carried out on the basis of laws / statutory provisions and that spatial planning is carried out by considering the sense of justice of the community and protecting the rights and obligations of all parties fairly with guaranteed legal certainty; (h) Accountability: that the implementation of spatial planning can be accounted for, both the process, the financing, and the results. ${ }^{30}$

A good and healthy environment is the basic right of every Indonesian citizen as mandated in Article $28 \mathrm{H}$ of the 1945 Constitution (UUD 1945). The implementation of spatial planning, and land use management in accordance with the regulations, will be able to prevent environmental damage or pollution.

Adrian Sutedi, Hukum Perizinan Dalam Sektor Pelayanan Publik (Jakarta: Sinar Grafika, 2017).

30 Ahmad Jazuli, "Penegakan Hukum Penataan Ruang Dalam Rangka Mewujudkan Pembangunan Berkelanjutan," Jurnal RechtsVinding 6, no. 2 (2017): 271.

104 
The conception of the criteria for an Environmental-based Regional Spatial Plan is based on a study of the conception of environmental protection and management, including: ${ }^{31}$ (a) Arranged in a systematic and planned, effective and efficient, and consistency; (b) In accordance with the carrying capacity of space and the environment, as well as natural and human resources; (c) Siding with the community; (d) Based on the principles of sustainability and sustainability, expediency, openness, fairness and legal certainty.

By adhering to the principles contained in the implementation of spatial planning, it can support the success of environmental management. The success in protecting and managing the environment is related to its objectives as stated in Article 3 of Law Number 32 Year 2009 concerning Environmental Protection and Management, can be seen from: (a) Protecting the territory of the Unitary Republic of Indonesia from pollution and/or environmental damage; (b) Guaranteed safety, health, and human life; (c) Guaranteed survival of living things and the preservation of ecosystems; (d) Preservation of environmental functions; (e) Achieving harmony, harmony, and environmental balance; (f) There is a guarantee of the fulfillment of justice of the present and future generations; (g) Guarantee the fulfillment and protection of the right to the environment as part of human rights; (h) Control of the wise use of natural resources; (i) Embodiment of sustainable development; and (j) Can anticipate global environmental issues.

\section{Conclusions}

Ways so that through land registration can support the success of environmental management: (1) Through a complete systematic land registration activity one can produce a one map policy. This one map policy will be useful for the central government (ministries/institutions) and regional governments in various geospatial data and information to synchronize and improve geospatial data so that it becomes a reference for all ministries or institutions and local governments in issuing permits and policies. Another benefit, every level of government with the policy of one map, will use the same basic map, because it uses one map of the same area, land that has been issued a management permit, can not be issued a management permit on the same plot of land. That is, it can avoid overlapping issuance of permits over land management; (2) The existence of a one map policy can also help in the formulation and implementation of regional spatial planning to realize integrated spatial planning that is

31 Arba, Hukum Tata Ruang Dan Tata Guna Tanah, Primsip-Prinsip Hukum Perencanaan Penataan Ruang Dan Penatagunaan Tanah (Jakarta: Sinar Grafika, 2017). 
harmonious with environmental sustainability, so that it can support the success of environmental management.

\section{Acknowledgment}

This research was supported by Faculty of Law Diponegoro University. We thank our colleagues from private law of Faculty of Law Diponegoro University who provided insight and expertise that greatly assisted the research.

\section{References}

Arba. Hukum Tata Ruang Dan Tata Guna Tanah, Primsip-Prinsip Hukum Perencanaan Penataan Ruang Dan Penatagunaan Tanah. Jakarta: Sinar Grafika, 2017.

CNN Indonesia. "BPN Target Terbitkan 11 Juta Sertifikat Tanah Gratis Di 2019." CNN Indonesia, 2019. https://www.cnnindonesia.com/nasional/20190321134316-20379420/bpn-target-terbitkan-11-juta-sertifikat-tanah-gratis-di-2019.

Harsono, Boedi. Hukum Agraria Indonesia, Sejarah Pembentukan Undang-Undang Pokok Agraria, Isi Dan Pelaksanaannya. Jakarta: Djambatan, 2008.

Hasni. Hukum Penataan Ruang Dan Penatagunaan Tanah Dalam Konteks UUPA-UUPRUUPLH. Jakarta: Rajawali Press, 2008.

Ibrahim, Johnny. Teori Dan Metodologi Penelitian Hukum Normatif. Malang: Bayumedia, 2006.

Ismail, Dian Ekawaty. Hukum Tata Ruang, Rekonstruksi Menuju Pemukiman Indonesia Bebas Kumuh. Yogyakarta: UII Press, 2018.

Ismaya, Samun. Hukum Administrasi Pertanahan. Yogyakarta: Graha Ilmu, 2013.

Jazuli, Ahmad. "Penegakan Hukum Penataan Ruang Dalam Rangka Mewujudkan Pembangunan Berkelanjutan.” Jurnal RechtsVinding 6, no. 2 (2017): 271.

Kantor Pertanahan Surabaya. "Mendukung Satu Kebijakan Peta Kantor Pertanahan Kota Surabaya Meluncurkan Kota Yang Lengkap.” Kantor Pertanahan Surabaya, 2018. https://www.atrbpn.go.id/News/ Press Release /.

Kurniati, Nia. Hukum Agraria Sengketa Pertanahan Penyelesaiannya Melalui Arbitrase Dalam Teori Dan Praktik. Bandung: Refika Aditama, 2016.

Perangin, Effendi. Hukum Agraria Indonesia. Jakarta: Rajawali Press, 1990.

Philip Reydon, Bastiaan; Vitor BukvarFernandes and Tiago SantosTelles. "Land Governance as a Precondition for Decreasing Deforestation in the Brazilian Amazon." Elsevier Journal, 
Land Use Policy 94, no. 104313 (2020).

Ristianto, Christoforus. "Timses Jokowi Sebut Isu Lingkungan Jadi Program Nawacita Jilid 2.” Kompas, 2018. https://nasional.kompas.com/read/2018/12/20/18203121/timses-jokowisebut-isu-lingkungan-jadi-program-nawacita-jilid-2 .

Satupeta. "Tentang Akselerasi Kebijakan Satu Peta (PKSP)." Satupeta, 2019. https://satupeta.go.id/about.

Sauni, Herawan. "Konflik Penguasaan Tanah Perkebunan." University of Bengkulu Law Journal (UBELAJ) 1, no. 1 (2016): 61.

Setiawan, Yudhi; Boedi Djatmiko Hadiatmodjo and Imam Ropii. Teori Dan Praktik Administrasi Hukum Pemerintah (Dilengkapi Dengan Beberapa Masalah Tanah). Jakarta: Rajawali Press, 2017.

Silviana, Ana. "Kebijakan Satu Peta Yang Mencegah Konflik Dalam Administrasi Pertanahan." Hukum Administrasi \& Jurnal Tata Pemerintahan 2, no. 2 (2019).

Soekanto, Soejono and Sri Mamudji. Penelitian Hukum Normatif, Tinjauan Singkat. Jakarta: Raja Grafindo Persada, 2007.

Sutedi, Adrian. Hukum Perizinan Dalam Sektor Pelayanan Publik. Jakarta: Sinar Grafika, 2017.

—. Peralihan Hak Atas Tanah Dan Pendaftarannya. Jakarta: Sinar Grafika, 2006.

Tehupeiory, Aartje. "Legal Protection To Individual Rights In Land Procurement For Public Interest.” Diponegoro Law Review 2, no. 1 (2017).

Thamrin, Juni. “Gagasan Menuju Pada Pengelolaan Sumber Daya Agraria Yang Partisipatif Dan Berkelanjutan.” Jurnal Analisis Sosial 6, no. 2 (2001).

Y.Imran, Suwitno. "Fungsi Tata Ruang Dalam Menjaga Kelestarian Lingkungan Hidup Kota Gorontalo.” Jurnal Dinamika Hukum 13, no. 3 (2013): 457. 